Original Research Paper

\title{
Adoption Factors of Electronic Human Resource Management (e-HRM) in Banking Industry of Bangladesh
}

\author{
${ }^{1,2}$ Abdul Kadar Muhammad Masum \\ ${ }^{I}$ Department of Business Administration, International Islamic University Chittagong, Bangladesh \\ ${ }^{2}$ Department of Administrative Studies and Politics, University of Malaya, Kuala Lumpur, Malaysia
}

Article history

Received: 12-02-2015

Revised: 1-3-2015

Accepted: 18-03-2015

\begin{abstract}
The purpose of the study is identifying the important factors that contribute to adoption of e-HRM among banks in Bangladesh. Stratified random sampling technique was used to consider 265 respondents from twenty eight private commercial banks. A pre-tested and close-ended questionnaire adapting five-point Likert scale was used for data collection. In this study, descriptive statistics and exploratory factor analysis are exercised as statistical tools. The result shows that employee's individual attributes, top management support, compatibility, IT infrastructure and industry pressure are important factors that influencing management decision to adopt e-HRM among banks. The practical implication of the findings is discussed at the end of this paper and recommendations for further research are also addressed.
\end{abstract}

Keywords: Electronic Human Resource Management (e-HRM), Adoption, Factors, Banks, Bangladesh

\section{Introduction}

Nowadays, the performance of Human Resource Management (HRM) is directly linked with organizational success (Masum et al., 2015). To achieve organizational goal, traditional HRM tools and techniques have been shifted to strategic HRM through a significant contribution of Information Technology (IT) (Rodríguez and Ventura, 2003). Organizations are increasingly implementing electronic Human Resource Management (e-HRM) as well as Human Resource Information System (HRIS) to meet the needs of HR professionals, managers and employees in HR activities for gaining competitive advantages (Thite et al., 2012). These systems provide a vital link between IT and HRM. Bondarouk et al. (2009) have recently claimed that e-HRM has been interchangeably coined with Human Resource Information System (HRIS), virtual HRM, web-based HRM and Intranet-based HRM.

In Bangladesh, large companies have started to implement e-HRM in last 5 years (Jahan, 2014). However, its implementation is still limited within the large companies in Bangladesh. Small companies and public companies have failed to realize the benefits of e-HRM and taken barely any inventiveness to implement the system. Since the discussion of e-HRM is still in its infancy, there is not much empirical research available glancing at the factors that foster the application of e-HRM (Jahan, 2014; Masum et al., 2013). So, the adoption decision and implementation of e-HRM can thus be seen as an innovation in Bangladesh. As like other countries, there are some factors that influence HR managers for implementing e-HRM in Bangladesh. This research will guide Bangladeshi managers to prepare for a successful shift from traditional HRM towards e-HRM and thus contribute to the economic development of the country.

The main thrust of this paper is identifying the most important factors that are linked to organizational adoption of e-HRM in the private banks of Bangladesh. The structure of this study is divided into seven sections. The second section demonstrated the related factors of e-HRM adoption. The following section includes a conceptual framework for the study. The research methods are discussed in section four. The findings of the study and discussion are addressed in section five and six respectively. In last section, conclusion describes the future research and recommendations with managerial implications. 


\section{Literature Review}

Due to the increasing use of Information System (IS) in the industrial operations, HR professionals became accustomed to use IS for HR activities from the early 1980's (Voermans and van Veldhoven, 2007). E-HRM is an integrated system covers a whole range of $\mathrm{HR}$ activities for the HR department. Usually, e-HRM contains some applications of labor force planning, supply and demand forecast, staffing information, applicant qualifications, information on training and development, salary forecast, pay increase, labor/employee relations, promotion-related information and so on (Bamel et al., 2014). Recent studies also confirmed that e-HRM improves the strategy formulation and decision making for HR activities. Therefore, it has been considered as a strategic partner of the firms (Thite et al., 2012; Wiblen et al., 2010).

Previous researchers explored that there are some important factors that influencing decision of e-HRM adoption among firms. In this section, we examined these factors on basis of e-HRM and innovation literature. These factors are categorized into individual level, organizational level, technological level and environmental level. Richter et al. (2013) found that the users' perception, attitude, motivation, intentions effect the adoption of IS and technologies. Similarly, past research also shows that users' attributes and their interaction with ISs decide the success or failure of ISs and technologies implementation (Delorme and Arcand, 2010; Troshani et al., 2011). Moreover, It was found in Singaporean SMEs that there is a great impact of top management (such as CEO) attitude towards IS adoption (Thong, 1999). In addition, IT skill of the employees and their familiarization with IT facilitate e-HRM adoption (Ruël et al., 2004; Voermans and van Veldhoven, 2007).

Among organizational factors firm size and skilled workforce are important factors in successful innovation adoption (Troshani et al., 2011). Moreover, numerous studies showed that top management commitment has a positive influence on e-HRM or IT adoption (Altarawneh and Al-Shqairat, 2010; Troshani et al., 2011). Furthermore, successful adoption of e-HRM requires availability of skilled e-HRM professionals in the organization. Because, lack of understanding of the system's functions and features may be a major obstacle in e-HRM adoption (Teo et al., 2007). Some studies identified the sufficient financial support as the key factor in the successful implementation of e-HRM (Parsa, 2007; Reddick, 2009).

To adopt a new technology, organizations encounter some barriers including innovation complexity and its compatibility with organizational technology competency and legacy systems (Rogers, 2003; Thong, 1999). Similarly, Teo et al. (2007), in their research in
Singapore, found only relative advantage and compatibility as influencing factors in e-HRM adoption. Moreover, Oliveira and Martins (2010) revealed that technology readiness is depended on organization's technology Infrastructure and IT professionals. They also stated technological readiness as a significant factor that influence IT adoption.

Environmental factors describe the external factors such as industry pressure that influencing adoption of eHRM (Kittipong, 2009; Troshani et al., 2011). Industry pressure denotes some drivers to adopt technology innovation so as to survive in the industry and keep its competitive advantages. As competitive pressure grows to reduce cost and serve more strategic role as well as to better manage the employees in the organizations, firms have realized that they cannot be competitive if they do not manage their human resources effectively (Teo et al., 2007; Thong, 1999). Thus, this need has driven the organizations to use e-HRM as it can help make more informed decision, more efficient HR processes and better allocate human resources.

\section{Conceptual Framework}

A conceptual model of managerial decision to adopt e-HRM among firms in Bangladesh was developed on basis of previous literature (Fig. 1). The conceptual model comprises of seven selected variables such as HR manager's attitude (Delorme and Arcand, 2010; Richter et al., 2013; Troshani et al., 2011), top management support (Altarawneh and Al-Shqairat, 2010; Teo et al., 2007; Troshani et al., 2011), IT infrastructure (Kwon and Zmud, 1987; Oliveira and Martins, 2010), compatibility (Rogers, 2003; Teo et al., 2007), complexity (Rogers, 2003; Thong, 1999), IT expertise (Ruël et al., 2004; Voermans and van Veldhoven, 2007) and competitive pressure (Kittipong, 2009; Teo et al., 2007; Thong, 1999).

\section{Methodologies of the Study}

A close-ended structured questionnaire was designed. Employing non-probability sampling technique, three hundred fifty (350) questionnaires were sent to senior HR persons such as HR managers, senior human resource director and IT experts of sample banks in Bangladesh. The response rate was $75.72 \%$ with 265 useable questionnaires. A five-point likert scale (where 1 $=$ strongly disagree and $5=$ strongly agree) was applied to measure the seven independent variables. Here, decision to adopt e-HRM was considered as a dependent variable. The duration of the survey was 3 months (from 1st August 2014 to 30th October 2014). The collected data was analyzed using Statistical Package for Social Sciences Program (SPSS) version 22.0. 
Independent variables

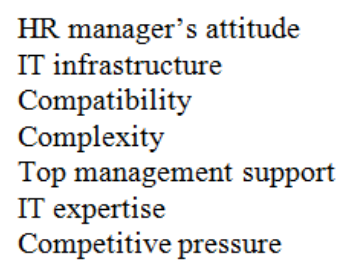

Fig. 1. Research framework

\section{Data Analysis and Findings}

\section{Validity and Reliability Analysis}

It is discovered most of the multi-item indicators confirmed enough convergent validity expect IT expertise and Complexity in factor analysis. Here, discriminant validity is also adequate as these items more strongly loaded on single factors than other factors. The sample size (265) of this study was statistically significant for factor analysis. The Kaiser-Meyer-Olkin (KMO) value for the overall matrix was 0.856 , which indicates sampling adequacy. Bartlett's test of sphericity (Bartlett, 1950) was applied to verify the appropriateness of the data for factor analysis. This test was also found to be significant. We found Cronbach's coefficient $(\alpha)$ for each dimension of the survey ranged from 0.72 to 0.92 (typically 0.6 and above is acceptable). The higher value of Cronbach's coefficient $(\alpha)$ indicates the better reliability (Cronbach, 1951; Malhotra, 2010).

\section{Influential Factor Extraction}

Here, Principal Component Analysis (PCA) followed by the varimax rotation was employed to categorize the most important factors that influencing e-HRM adoption. There were 36 items in the study. Table 1 shows item loading values, Cronbach's alpha and Eigen values. The variable loading value of above 0.50 are considered significant variable (Hair et al., 2003). Some variables were dropped from the analysis due to low loading values. The 36 items of e-HRM adoption scale were reduced to 18 items after Exploratory Factor Analysis (EFA) was run. Here, five factors are extracted. Five factors below extracted in the EFA together explained $58.264 \%$ of the total variance:

- The first extracted factor is Top management support. This factor is represented by four variables, which accounted for $17.789 \%$ of the variance. The factor loadings of the variables range from 0.778 to 0.881 . The four items are: Top management is aware of the advantages of e-HRM; top management has a strategic plan for e-HRM; top management has allocated adequate resources for e-HRM implementation; top management inspires HR personnel to use e-HRM in all HR related issues; top management enthusiastically expenses IT infrastructure; and top management has sufficient financial support for IT infrastructure

- The second extracted factor is HR manager's attitude. This factor is represented by four variables, which accounted for $14.235 \%$ of the variance. The factor loadings of the variables range from 0.635 to 0.845 . The four items are: I consider adoption of eHRM as a wise decision for the company; I consider that e-HRM contributes to HRM strategic effectiveness; I consider that e-HRM contributes to HRM technical effectiveness; and HR managers fell comfort with e-HRM applications

- The third extracted factor is IT infrastructure. This factor is represented by four variables, which accounted for $12.783 \%$ of the variance. The factor loadings of the variables range from 0.501 to 0.814 . The four items are: e-HRM applications are compatible with existing IT infrastructure; the firm has a secure networking system; the firm has speedy internet facility; and the firm has a strong backup plan for network failure

- The fourth extracted factor is Compatibility. This factor is represented by three variables, which accounted for $8.345 \%$ of the variance. The factor loadings of the variables range from 0.518 to 0.801 . The three items are: e-HRM applications are compatible with existing operating practices; e-HRM applications are compatible with organization's computerized data resources; and e-HRM applications are compatible with existing IT infrastructure

- The fifth extracted factor is Competitive pressure is the extracted fifth factor. This factor is represented by three variables, which accounted for $5.112 \%$ of the variance. The factor loadings of the variables range from 0.511 to 0.722 . The three items are: The overall operational practices in our industry pressure us to adopt e-HRM; we actively keep track of innovative usage of technology by competitors; and it is becoming strategic need to use e-HRM application to strive in the industry 


\begin{tabular}{|c|c|c|c|c|c|}
\hline Factor name & Items & Item loading & $\begin{array}{l}\text { \% of variance } \\
\text { (Cumulative) }\end{array}$ & $\begin{array}{l}\text { Cronbach's } \\
\text { reliability coefficient }\end{array}$ & Eigen value \\
\hline \multicolumn{6}{|l|}{ Factor \#1 } \\
\hline \multirow[t]{4}{*}{ Top management support } & Top2 & 0.881 & $17.789(17.789)$ & 0.92 & 10.879 \\
\hline & Top3 & 0.823 & & & \\
\hline & Top1 & 0.791 & & & \\
\hline & Top4 & 0.778 & & & \\
\hline \multicolumn{6}{|l|}{ Factor \#2 } \\
\hline \multirow[t]{4}{*}{ HR manager's attitude } & Att1 & 0.845 & $14.235(32.024)$ & 0.86 & 6.564 \\
\hline & Att4 & 0.812 & & & \\
\hline & Att3 & 0.765 & & & \\
\hline & Att2 & 0.635 & & & \\
\hline \multicolumn{6}{|l|}{ Factor \#3 } \\
\hline \multirow{4}{*}{ IT infrastructure } & Infr4 & 0.814 & $12.783(44.807)$ & 0.72 & 4.786 \\
\hline & Infr2 & 0.745 & & & \\
\hline & Infr3 & 0.618 & & & \\
\hline & Infr1 & 0.501 & & & \\
\hline \multicolumn{6}{|l|}{ Factor \#4 } \\
\hline \multirow[t]{3}{*}{ Compatibility } & Comp1 & 0.801 & $8.345(53.152)$ & 0.91 & 2.887 \\
\hline & Comp4 & 0.688 & & & \\
\hline & Comp3 & 0.518 & & & \\
\hline \multicolumn{6}{|l|}{ Factor \#5 } \\
\hline \multirow[t]{3}{*}{ Competitive pressure } & Env4 & 0.722 & $5.112(58.264)$ & 0.87 & 1.234 \\
\hline & Env2 & 0.574 & & & \\
\hline & Env3 & 0.511 & & & \\
\hline
\end{tabular}

Source: Developed by the authors on the basis of data collected for the present study

IT expertise and Complexity were dropped by PCA as the item loading for the related variables were below 0.5 .

\section{Discussion}

In the present study, the findings direct that top management support, HR professionals attribute, IT infrastructure, complexity and competitive pressure are important factors for the managerial decision of eHRM adoption. However, IT expertise and complexity are not extracted as factors that are not influencing for e-HRM adoption among banks in Bangladesh.

Numerous researchers revealed that HR manager's attitude (Delorme and Arcand, 2010; Kittipong, 2009; Richter et al., 2013; Troshani et al., 2011) affect adoption of any technological innovation that is similar to our findings. The results of data analysis demonstrated that top management support is a determinant of e-HRM adoption among banks in Bangladesh. The extracted determinant is identical to the past research. The earlier research identified top management support as a vital issue for the organizational adoption of technology innovation (Altarawneh and Al-Shqairat, 2010; Teo et al., 2007; Troshani et al., 2011). IT Infrastructure is another vital factor to influence the organizational decision to adopt e-HRM. This finding support previous research (Kwon and Zmud, 1987; Oliveira and Martins, 2010). The extracted factor-compatibility supports the previous research, where it is identified one of the most significant factors to take decision for e-HRM adoption (Rogers, 2003; Thong, 1999). Finally, competitive pressure has influence to adopt e-HRM among firms in Bangladesh. This finding is consistent with earlier studies (Kittipong, 2009; Teo et al., 2007; Thong, 1999).

\section{Conclusion}

The intention of this study was to investigate factors influencing e-HRM adoption in private commercial banks of Bangladesh. The findings of the study suggested that top management support, HR managers' attribute, IT infrastructure, compatibility and industry pressure are the important determinants to the adoption of e-HRM. The research has contributed to the body of knowledge in the area of e-HRM research through providing a greater understanding and important insights into the determinants factors that affecting the organizational adoption of e-HRM within Bangladesh context. There are some limitations that exist during the process of this research. The sample size of the study is chosen only 265 . It is agreed that the bigger the sample is, the more representative the results are. Moreover, we have chosen seven determinants to investigate the decision of e-HRM adoption, but there are also many other potential determinants that may affect the decision of e-HRM adoption. 


\section{Acknowledgment}

The author would like to thank and acknowledge Dr. Beh Loo See, Associate Professor, University of Malaya, Malaysia for her contribution in editing and proof reading this manuscript.

\section{Funding Information}

The author has no support or funding to report.

\section{Conflict of Interest}

There is no conflict of interes.

\section{Ethics}

This article is original and contains unpublished material. The corresponding author confirms that all of the other authors have read and approved the manuscript and no ethical issues involved.

\section{References}

Altarawneh, I. and Z. Al-Shqairat, 2010. Human resource information systems in Jordanian universities. Int. J. Bus. Manage., 5: 113-127. DOI: $10.5539 / \mathrm{ijbm} . v 5 \mathrm{n} 10 \mathrm{p} 113$

Bamel, N., U. Kumar Bamel, V. Sahay and M. Thite, 2014. Usage, benefits and barriers of human resource information system in universities. VINE, 44: 519-536. DOI: 10.1108/VINE-04-2013-0024

Bartlett, M.S., 1950. Tests of significance in factor analysis. Br. J. Stat. Psychol., 3: 77-85. DOI: $10.1111 / j .2044-8317.1950 . t b 00285 . x$

Bondarouk, T., H. Ruel and B. van der Heijden, 2009. E-HRM effectiveness in a public sector organization: A multi-stakeholder perspective. Int. J. Hum. Resource Manage., 20: 578-590. DOI: 10.1080/09585190802707359

Cronbach, L.J., 1951. Coefficient alpha and the internal structure of tests. Psychometrika, 16: 297-334. DOI: 10.1007/BF02310555

Delorme, M. and M. Arcand, 2010. HRIS implementation and deployment: A conceptual framework of the new roles, responsibilities and competences for HR professionals. Int. J. Bus. Inform. Syst., 5: 148-161. DOI: $10.1504 / \mathrm{IJBIS} .2010 .030626$

Hair, J., R. Anderson, R. Tatham and W. Black, 2003. Multivariate Data Analysis. 1st Edn., Peasrson Education, New Delhi.

Jahan, S., 2014. Human Resources Information System (HRIS): A theoretical perspective. J. Hum. Resource Sustainability Stud., 2: 33-39. DOI: $10.4236 /$ jhrss.2014.22004
Kittipong, S., 2009. The adoption of techno-relationship innovations: A framework for electronic customer relationship management. Market. Intell. Professionals, 27: 380-412. DOI: 10.1108/02634500910955254

Kwon, T.H. and R.W. Zmud, 1987. Unifying the Fragmented Models of Information Systems Implementation. In: Critical Issues in Information Systems Research, Boland, R.J. and R. Hirschheim (Eds.), Wiley, Chichester, ISBN-10: 0471912816, pp: 227-251.

Malhotra, N., 2010. Marketing Research: An Applied Orientation. 1st Edn., Pearson Education, New Jersey, ISBN-10: 8131731812, pp: 1000.

Masum, A.K.M., M.A.K. Azad and L.S. Beh, 2015. The role of human resource management practices in bank performance. Total Quality Manage. Bus. Excell. DOI: 10.1080/14783363.2014.1002762

Masum, A.K.M., F. Bhuiyan and R. Kabir, 2013. HRIS practices in universities: An exploratory study on the private universities in Bangladesh. Global J. Hum. Soc. Sci. Res.

Oliveira, T. and M.F. Martins, 2010. Understanding e-business adoption across industries in European countries. Ind. Manage. Data Syst., 110: 1337-1354. DOI: $10.1108 / 02635571011087428$

Parsa, H., 2007. Critical factors in implementing HRIS in restaurant chains. Adv. Hospitality Leisure, 3: 69-86.

Reddick, C.G., 2009. Human resources information systems in Texas City governments: Scope and perception of its effectiveness. Public Personnel Manage., 38: 19-34. DOI: $10.1177 / 009102600903800402$

Richter, A., A. Stocker, S. Müller and G. Avram, 2013. Knowledge management goals revisited: A cross-sectional analysis of social software adoption in corporate environments. VINE, 43: 132-148. DOI: $10.1108 / 03055721311329927$

Rodríguez, J.M. and J. Ventura, 2003. Human resource management systems and organizational performance: an analysis of the Spanish manufacturing industry. Int. J. Hum. Resource Manage., 14: 1206-1226. DOI: $10.1080 / 0958519032000114273$

Rogers, E.M., 2003. Diffusion of Innovation. 5th Edn., Simon and Schuster, ISBN-10: 0743258231, pp: 576.

Ruël, H., T. Bondarouk and J.K. Looise, 2004. E-HRM: Innovation or irritation. An explorative empirical study in five large companies on web-based HRM. Manage. Revue, 15: 364-380.

Teo, T.S., G.S. Lim and S.A. Fedric, 2007. The adoption and diffusion of human resources information systems in Singapore. Asia Pacific J. Hum. Resources, 45: 44-62. DOI: $10.1177 / 1038411107075402$ 
Thite, M., M.J. Kavanagh and R.D. Johnson, 2012. Evolution of Human Resource Management and Human Resource Information Systems: The Role of Information Technology. In: Human Resource Information Systems: Basics, Applications and Future Directions, Kavanagh, M.J., M. Thite and R.D. Johnson (Eds.), Sage Publications, Thousand Oaks, CA.

Thong, J.Y., 1999. An integrated model of information systems adoption in small businesses. J. Manage. Inform. Syst., 15: 187-214.
Troshani, I., C. Jerram and S. Rao Hill, 2011. Exploring the public sector adoption of HRIS. Ind. Manage. Data Syst., 111: 470-488.

DOI: $10.1108 / 02635571111118314$

Voermans, M. and M. van Veldhoven, 2007. Attitude towards E-HRM: An empirical study at Philips. Personnel Rev., 36: 887-902. DOI: $10.1108 / 00483480710822418$

Wiblen, S., D. Grant and K. Dery, 2010. Transitioning to a new HRIS: The reshaping of human resources and information technology talent. J. Electronic Commerce Res., 11: 251-267. 